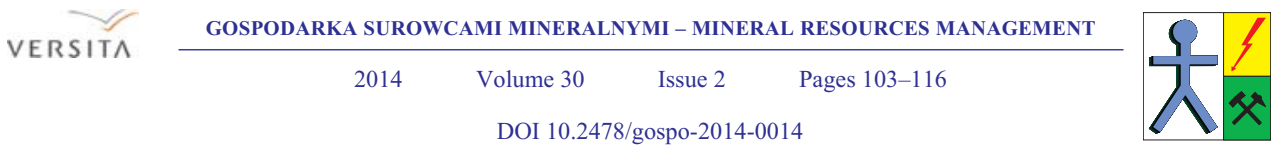

\title{
Alkali activation of fresh and deposited black coal fly ash with high loss on ignition
}

\section{Introduction}

Power stations using coal as a fuel are employed worldwide as energy sources, consequently generating large quantities of fly ashes. However, only a small part of these ashes are utilized. Although fly ashes can be used in the construction industry, the European standard STN EN 206-1 limits their content of unburned coal residues to 2-5\% LOI (loss on ignition). The unburned carbon in fly ashes has several detrimental effects on concrete. Most importantly, it increases the electrical conductivity of concrete, and changes the color of mortar and concrete. Moreover, the water/cement+fly ash ratio, needed to obtain a cement paste with the required rheological properties or consistency, is higher for fly ash with a high carbon content, which increases the corrosivity of metallic parts incorporated into the concrete (Ha et al. 2005). Thus, fly ashes produced in eastern Slovakia, having a high content of unburned coal residues (more than 10\% LOI), cannot be utilized as a secondary raw material for building materials. Currently, one possibility for the utilization of high-LOI fly ashes is in the synthesis of geopolymers.

Geopolymers are inorganic materials obtained from the chemical reaction of alumino-silicate oxides with sodium silicate solutions in a highly alkaline environment, yielding polymeric Si-O-Al bonds. The network consists of $\mathrm{SiO}_{4}$ and $\mathrm{AlO}_{4}$ tetrahedra linked

* Ing. PhD., ** Ing., Technical University in Košice, Institute of Montaneous Sciences and Environmental Protection, Faculty of Mining, Ecology, Process Control and Geotechnologies, Košice, Slovak Republic; e-mail: martin.sisol@tuke.sk; miroslava.drabova@tuke.sk; juraj.mosej@tuke.sk 
alternately by sharing all the oxygens. The $\mathrm{Al}^{3+}$ in IV-fold coordination demands the presence of cations in the framework to balance the negative charge. The empirical formula of geopolymers, also known as poly(sialates) is $\mathrm{M}_{\mathrm{n}}\left\{-\left(\mathrm{SiO}_{2}\right)_{\mathrm{z}}-\mathrm{AlO}_{2}\right\}_{\mathrm{n}} \cdot \mathrm{wH}_{2} \mathrm{O}$, where $\mathrm{M}$ is a cation such as $\mathrm{K}^{+}, \mathrm{Na}^{+}$, or $\mathrm{Ca}^{2+} ; n$ is the degree of polycondensation and $z$ is 1,2 , or 3 (Davidovits 1990). The geopolymerisation process involves the dissolution of $\mathrm{Al}$ and $\mathrm{Si}$ from the surface, the diffusion of the dissolved species, the polycondensation of the $\mathrm{Al}$ and $\mathrm{Si}$ complexes, and the formation of a gel and its hardening that results in the final geopolymeric product (Davidovits 2008; Panias et al. 2007; Xu and Deventer 2000). Geopolymerization could convert alumino-silicate wastes into value-added products with excellent physical and chemical properties as well as long-term durability (Xu and Deventer 2002).

Fly ash is a good raw material for making geopolymers owing to its high content of silica and alumina (Fernández-Jiménez et al. 2006; Fernández-Jiménez and Palomo 2003; Jaarsveld et al. 2003; Škvára et al. 2005). There are several factors that influence the ability of fly ashes to be alkaline activated. The most important are particle size distribution (Temuujin et al. 2009; Kumar and Kumar 2011), content of vitreous phase (Criado et al. 2007), Si/Al ratio in vitreous phase (Fernández-Jiménez et al. 2006b; Duxson et al. 2007), calcium content (Yip et al. 2005, 2008; Lee and Deventer 2002), and the percentage of unburned material (Fernández-Jiménez and Palomo 2003). According to studies (Fernández-Jiménez and Palomo 2003; Jaarsveld et al. 1997, 1999), particles of unburned coal residues act as inert particles and are responsible for increasing the liquid/solid ratio. A high content of unburned coal residues in fly ash results in lower compressive strength and increased porosity of a geopolymer.

Most researchers worldwide use ashes with unburned coal residues content below 5\% for alkali activation. The present study investigates the feasibility of using fly ash with more than $20 \%$ unburned coal residues as a raw material for the synthesis of geopolymers. This paper compares the properties of geopolymers made using fresh fly ash taken directly from the fly ash hopper, and fly ash that was landfilled for several years and thus subjected to various environmental attacks.

\section{Experimental Section}

\subsection{Characterization of fly ashes}

Two kinds of fly ash were used in this study. Both of the fly ashes were derived from black coal combusted in the melting boilers of a District Heating Plant in Košice (Slovakia) at a temperature of $1400-1550^{\circ} \mathrm{C}$. Fresh fly ash (called FFA) was derived from a fly ash hopper, and deposited fly ash (called DFA) was obtained from an upper layer of the coal-ash sludge bed in Krásna nad Hornádom. Partial chemical analyses of these ashes are indicated in Table 1 . The fly ashes are characterised by a high content of unburned coal residues up to $20 \%$ and a $\mathrm{SiO}_{2} / \mathrm{Al}_{2} \mathrm{O}_{3}$ ratio of 2.98 and 2.40 for the deposited fly ash and fresh fly ash, 
Table 1. Partial chemical composition of fly ashes

Tabela 1. Skład chemiczny popiołów lotnych

\begin{tabular}{|c|c|c|c|c|c|c|c|}
\hline wt. $\%$ & $\mathrm{SiO}_{2}$ & $\mathrm{Al}_{2} \mathrm{O}_{3}$ & $\mathrm{Fe}_{2} \mathrm{O}_{3}$ & $\mathrm{CaO}$ & $\mathrm{MgO}$ & $\mathrm{LOI}$ & $\mathrm{SiO}_{2} / \mathrm{Al}_{2} \mathrm{O}_{3}$ \\
\hline DFA & 46.77 & 15.69 & 8.34 & 3.93 & 1.21 & 23.25 & 2.98 \\
\hline FFA & 47.84 & 19.90 & 7.21 & 1.73 & 1.41 & 20.60 & 2.40 \\
\hline
\end{tabular}

Table 2. Mineralogical composition of fly ashes

Tabela 2. Skład mineralny popiołów lotnych

\begin{tabular}{|c|c|c|c|c|c|c|c|}
\hline wt.\% & Amorphous & Hematite & Quartz & Mullite 21 & Mullite 32 & Cristobalite & Magnetite \\
\hline DFA & $83.56 \pm 2.04$ & $1.57 \pm 0.93$ & $6.42 \pm 0.96$ & $8.46 \pm 1.83$ & - & - & - \\
\hline FFA & $83.92 \pm 2.07$ & - & $5.76 \pm 1.02$ & - & $8.57 \pm 1.62$ & $0.87 \pm 0.66$ & $0.87 \pm 0.54$ \\
\hline
\end{tabular}

respectively. The mineralogical composition of the fly ashes is presented in Table 2 . The phase analysis was performed using the X-ray diffractometer URD-6/ID 3003 (Rich. Seifert-FPM, Germany) under the following conditions: X-ray radiation Co Ka, high voltage of $40 \mathrm{kV}$, current of $35 \mathrm{~mA}$, step scan mode with step of $0.05^{\circ} 2 \theta$, time per step $3 \mathrm{~s}$. For chemical analysis, the atomic absorption spectroscopy (AAS) (Perkin Elmer instrument, model 1100B) was used.

The morphology of the fly ash (Fig. 1) was observed by scanning electron microscopy (SEM) using a Jeol JSM 7000F with analytical units EDX, EBSD Oxford Instruments. EDX

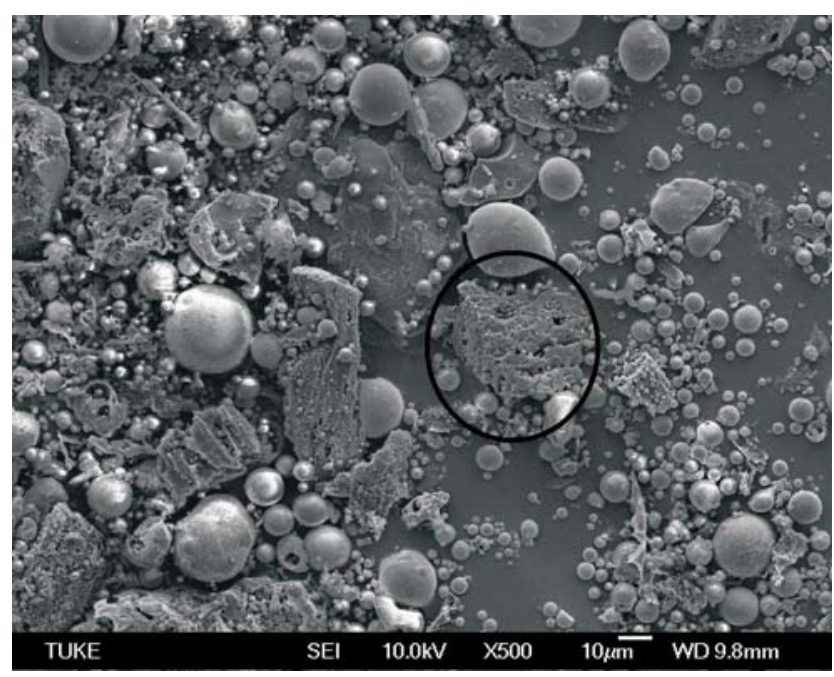

Fig. 1. Morphology of deposit fly ash (SEM)

Rys. 1. Morfologia deponowanego popiołu lotnego (SEM) 
analysis of selected particles found in black coal fly ash revealed the presence of silicon, aluminum, and iron oxides in the form of spherical particles. Particles of unburned coal residues (the particle in a circle) are porous with irregular shape.

To determine the leachability of Al and Si from the fly ashes (Phair and Deventer 2001), their concentrated suspensions were prepared in a $10 \mathrm{M} \mathrm{NaOH}$ solution. The suspensions, containing $24 \mathrm{~g}$ of solid dispersed in $50 \mathrm{ml}$ of solution, were mixed for 24 hours, centrifuged, filtered, and diluted with $5 \%$ content $\mathrm{HCl}$ before analysis of the elemental concentrations by AAS (Table 3).

Table 3. Content of $\mathrm{SiO}_{2}$ and $\mathrm{Al}_{2} \mathrm{O}_{3}$ in the $10 \mathrm{M} \mathrm{NaOH}$ leaching solution after 24 hours

Tabela 3. Zawartość $\mathrm{SiO}_{2}$ i $\mathrm{Al}_{2} \mathrm{O}_{3}$ po ługowaniu w 10 -molowym roztworze $\mathrm{NaOH}$ przez 24 godziny

\begin{tabular}{|c|c|c|}
\hline Material & DFA & FFA \\
\hline $\mathrm{SiO}_{2}\left[\mathrm{mg} .1^{-1}\right]$ & 780 & 14180 \\
\hline $\mathrm{Al}_{2} \mathrm{O}_{3}\left[\mathrm{mg} . \mathrm{l}^{-1}\right]$ & 675 & 628 \\
\hline
\end{tabular}

The long time exposure of DFA to atmospheric influences and erosion partially changed the chemical (Table 1) and mineralogical composition (Table 2). The content of amorphous phase of both fly ashes was approximately the same (83\%). Some differences were observed for iron and mullite; in FFA, iron occurred as magnetite $\left(\mathrm{Fe}_{3} \mathrm{O}_{4}\right)$ and mullite with the stochiometric composition $3 \mathrm{Al}_{2} \mathrm{O}_{3} 2 \mathrm{SiO}_{2}$; whereas in DFA, iron occurred as hematite $\left(\mathrm{Fe}_{2} \mathrm{O}_{3}\right)$ and mullite with the stochiometric composition $2 \mathrm{Al}_{2} \mathrm{O}_{3} \mathrm{SiO}_{2}$. Loss on ignition of both fly ashes was relatively high, $20.60 \%$ and $23.25 \%$ for FFA and DFA, respectively. FFA was more reactive than DFA as a higher portion of $\mathrm{SiO}_{2}$ was released from FFA during leaching in the $10 \mathrm{M} \mathrm{NaOH}$ (Table 3).

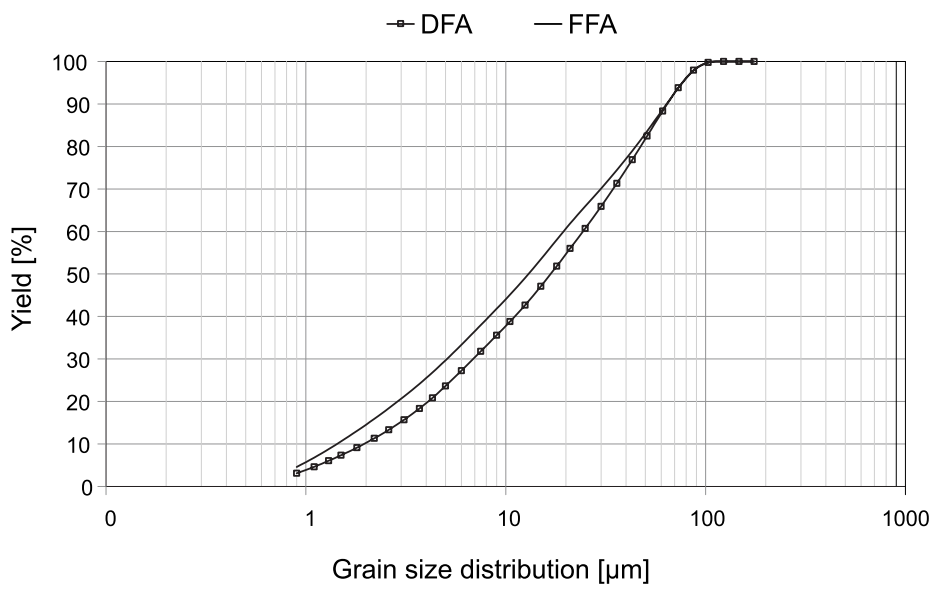

Fig. 2. Grain size distributions of deposit and fresh fly ashes

Rys. 2. Skład ziarnowy popiołów lotnych deponowanych i z bieżącej działalności 
Particle size distribution is the most significant physical characteristic of fly ash in terms of affecting its reactivity. Grain size distribution of both fly ashes was obtained by the Diffraction Spectrometer Helos 12 LA (Sympatec GmbH, Germany) with a dispersing Feeder Rodos 12 SR for dry, pulverulent solids: granulometric analysis in the range of particles $0.9-170$ micrometers. Grading curves of both fly ashes in Figure 2 shows only a small difference between FFA and DFA. The fly ash contains $50 \%$ of particles sized lower than $13 \mu \mathrm{m}$ and $17 \mu \mathrm{m}$ for FFA and DFA, respectively.

\subsection{Alkali activation of the fly ashes}

Binder was prepared by blending fly ash with activation solution. The $\mathrm{SiO}-$ to- $\mathrm{Na}_{2} \mathrm{O}$ ratio (Ms modulus) in the activation solution was adjusted by $\mathrm{NaOH}$ addition to the sodium water glass. Sodium water glass from the Kittfort Praha Co. with a density of $1.328-1.378 \mathrm{~g} / \mathrm{cm}^{3}$ was used. It contains $36-38 \% \mathrm{Na}_{2} \mathrm{SiO}_{3}$, and the molar ratio of $\mathrm{SiO}_{2}$-to- $\mathrm{Na}_{2} \mathrm{O}$ is 3.2-3.5. Solid $\mathrm{NaOH}$ with a density of $2.13 \mathrm{~g} / \mathrm{cm}^{3}$ was obtained from different producers, but they all had similar chemical compositions and physical properties, containing at least $98 \% \mathrm{NaOH}$ and up to $1 \% \mathrm{Na}_{2} \mathrm{CO}_{3}$. The value of the Ms modulus in the activation solution ranged from 0.75 to 1.65 . The overall concentration of the alkaline activation agent ranged from 6 to $9 \%$ $\mathrm{Na}_{2} \mathrm{O}$ in the binder mass. The water-to-fly ash ratio ranged from 0.30 to 0.35 . The pastes were cured in a hot air drying chamber at $80^{\circ} \mathrm{C}$ for 6 hours. Thereafter, the samples were removed from the forms, marked, and stored in laboratory conditions till the moment of the strength test.

\subsection{Mechanical properties of alkali activated fly ashes}

The mechanical properties of the resulting products were studied on prismatic specimens with the dimensions $40 \times 40 \times 160 \mathrm{~mm}$. The values of compressive strength were determined after 7, 28, and 90 days according to the Slovak Standard STN EN 12390-3 using the hydraulic machine Form+Test MEGA 100-200-10D. A part of the samples was kept for 28 days at laboratory temperature, then a water absorption test according to the Slovak Standard STN 731316 was performed, after which they were subjected to alternating freezing and defrosting cycles according to the Slovak Standard STN 731325.

\section{Results and Discussion}

\subsection{Effect of $\mathrm{Na}_{2} \mathrm{O}$}

In Figure 3 the values of compressive strengths for two fly ashes geopolymers and their evolution over time ( 7 and 90 days) are shown. The results indicate that higher compressive strengths are obtained for the FFA-geopolymer, which could be associated with 


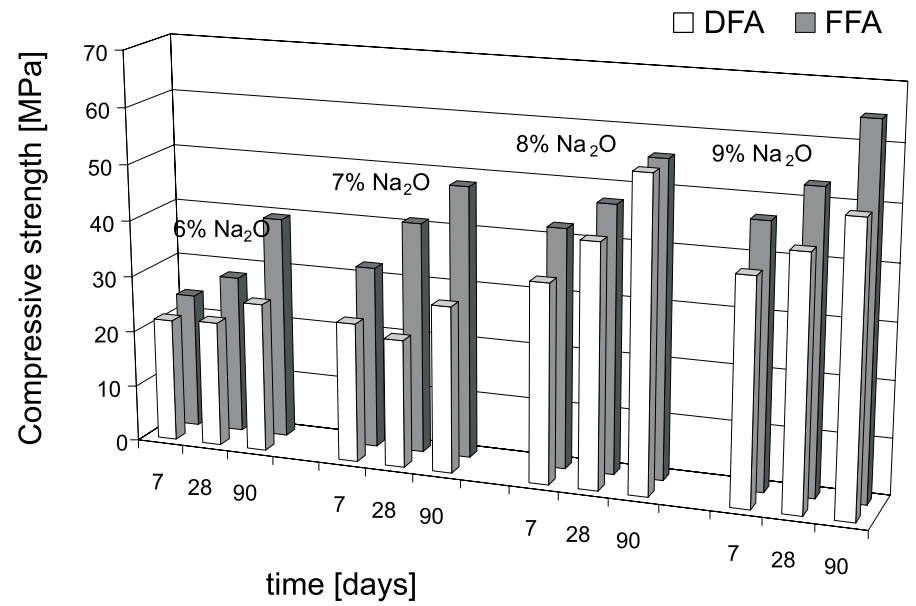

Fig. 3. Compressive strength of both types of examined geopolymers with their evolution over time (7 and 90 days) depending on different $\mathrm{Na}_{2} \mathrm{O}$ concentrations. Water-to-fly ash ratio was constant at 0.3

Rys. 3. Wytrzymałość na ściskanie obydwu typów badanych geopolimerów po 7 i 90 dniach w zależności od koncentracji $\mathrm{Na}_{2} \mathrm{O}$. Stosunek wody do popiołu stały: 0,3

the high reactivity of fresh fly ash (Table 3). The mechanical strength of alkali-activated fly ashes increases with time until the 90th day of observation. The increase in $\mathrm{Na}_{2} \mathrm{O}$ concentration in mixtures has a positive effect on the compressive strength of geopolymers. The maximum value of the DFA-geopolymer compressive strength was obtained with an $8 \%$ $\mathrm{Na}_{2} \mathrm{O}$ concentration (55.3 MPa after 90 days). A further increase in $\mathrm{Na}_{2} \mathrm{O}$ concentration results in a decrease in the achieved compressive strengths. The maximum compressive strength of the FFA-geopolymer was obtained with a $9 \% \mathrm{Na}_{2} \mathrm{O}$ concentration $(64.9 \mathrm{MPa}$ after 90 days).

The same trend can be seen for both fly ashes; the greater the concentration of $\mathrm{Na}_{2} \mathrm{O}$, the smaller the water absorption of geopolymers. FFA-geopolymers achieve higher water absorption than DFA-geopolymers, the only exception being the geopolymer with a $9 \%$ $\mathrm{Na}_{2} \mathrm{O}$ concentration of the fly ash mass with lower water absorption of the FFA-geopolymer (6.11\%) than the DFA-geopolymer (6.71\%) prepared by the same method (Table 4).

Increasing compressive strength results in decreasing water absorption of the geopolymer. Nevertheless, the FFA-geopolymers having higher compressive strength achieve higher water absorption in comparison with the DFA-geopolymers.

The frost resistance of the fly ash geopolymer materials was examined using 25 freezing and defrosting cycles for the DFA-geopolymer and 50 freezing and defrosting cycles for the FFA-geopolymer in an aqueous environment. The values of compressive strength of the geopolymers were compared with the values obtained for the geopolymers without any frost resistance testing (reference samples). In Table 4 the values of the coefficients of freezing for the geopolymers are shown. No damage or deformation could be detected after defrosting cycles in the aqueous environment. The frost resistance of the DFA-geopolymers was better; 
Table 4. Values of water absorption and coefficient of freezing for DFA and FFA-geopolymers depending on different $\mathrm{Na}_{2} \mathrm{O}$ concentrations

Tabela 4. Wartości nasiąkliwości wodnej i mrozoodporności dla geopolimerów DFA i FFA w zależności od koncentracji $\mathrm{Na}_{2} \mathrm{O}$

\begin{tabular}{|c|c|c|c|c|c|}
\hline \multirow{3}{*}{ Material } & water-to-fly ash & $\mathrm{SiO}_{2}$-to- $\mathrm{Na}_{2} \mathrm{O}$ & $\begin{array}{c}\mathrm{Na}_{2} \mathrm{O} \\
{[\%]}\end{array}$ & $\begin{array}{c}\text { Water absorption } \\
{[\%]}\end{array}$ & $\begin{array}{c}\text { Coeficient of } \\
\text { freezing }\end{array}$ \\
\hline \multirow{5}{*}{ DFA } & 0.3 & 1.25 & 6 & 13.48 & 1.47 \\
\cline { 2 - 6 } & 0.3 & 1.25 & 7 & 11.04 & 1.81 \\
\cline { 2 - 6 } & 0.3 & 1.25 & 8 & 6.62 & 1.54 \\
\hline \multirow{5}{*}{ FFA } & 0.3 & 1.25 & 9 & 6.71 & 1.28 \\
\cline { 2 - 6 } & 0.3 & 1.25 & 6 & 15.76 & 0.69 \\
\cline { 2 - 6 } & 0.3 & 1.25 & 7 & 13.16 & 0.83 \\
\hline & 0.3 & 1.25 & 8 & 10.27 & 0.79 \\
\hline
\end{tabular}

higher values of compressive strength in comparison with references after 25 cycles were achieved. The strength of the FFA-geopolymers after 50 cycles decreased when compared to the reference samples.

Given the results measured, an $8 \% \mathrm{Na}_{2} \mathrm{O}$ concentration was chosen and utilized in the next experiments.

\subsection{Effect of the $\mathrm{SiO}_{2}$-to- $\mathrm{Na}_{2} \mathrm{O}$ molar ratio}

Figure 4 shows the compressive strengths of both types of examined geopolymers with their evolution over time ( 7 and 90 days) depending on different $\mathrm{SiO}_{2}$-to- $\mathrm{Na}_{2} \mathrm{O}$ molar ratios. It is evident that the FFA-geopolymers achieve higher values of compressive strength than the DFA-geopolymers. The most significant difference in the value of compressive strength was observed when fly ashes were alkali activated using activator with a $\mathrm{SiO}_{2}-$ to- $\mathrm{Na}_{2} \mathrm{O}$ molar ratio of 0.75 . On the other hand, fly ashes activated by activator with a $\mathrm{SiO}_{2}-\mathrm{to}-\mathrm{Na}_{2} \mathrm{O}$ molar ratio of 1.25 after 90 days storage at the laboratory temperature achieved similar values of compressive strength; 55.3 MPa and 55.8 MPa for DFA- and FFA-geopolymer, respectively.

The values of the compressive strength of the fly ash geopolymers increase with an increasing $\mathrm{SiO}_{2}$-to- $\mathrm{Na}_{2} \mathrm{O}$ ratio from 0.75 to 1.25 . However, a further increase in the $\mathrm{SiO}_{2}$-to- $\mathrm{Na}_{2} \mathrm{O}$ ratio causes a decrease in the achieved compressive strengths. The compressive strength values of the DFA-geopolymers differing in $\mathrm{SiO}_{2}-\mathrm{to}-\mathrm{Na}_{2} \mathrm{O}$ molar ratio vary. At the same time, the compressive strength of the FFA-geopolymers with a molar ratio of $0.75,1.00$, and 1.25 achieve very similar values of $53.3,51.6$, and $55.8 \mathrm{MPa}$, and small differences in compressive strength values of 44.7 and $43.3 \mathrm{MPa}$ are observed for the 1.50 and 1.65 ratios, respectively. 


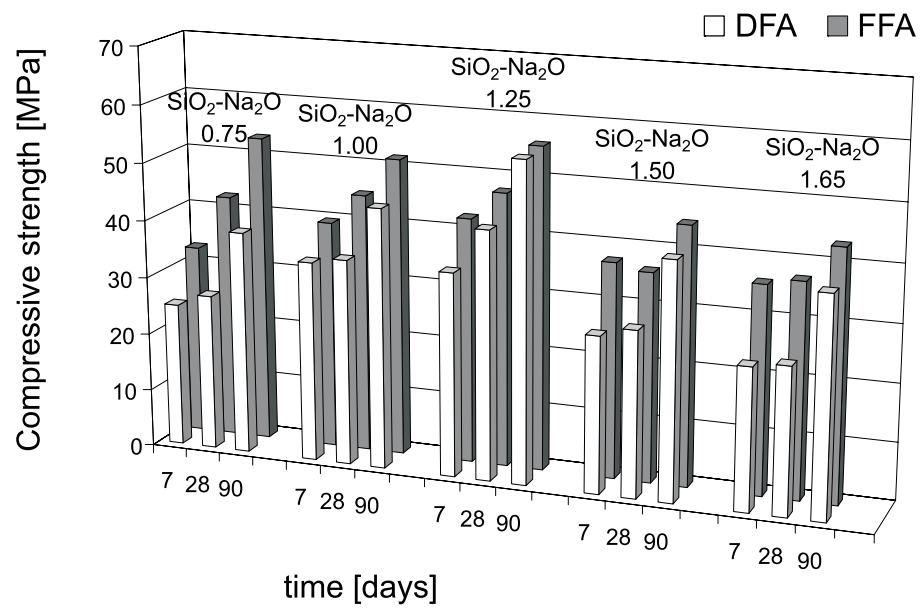

Fig. 4. Compressive strength of both types of examined geopolymers with their evolution over time (7 and 90 days) depending on different $\mathrm{SiO}_{2}$-to- $\mathrm{Na}_{2} \mathrm{O}$ molar ratios. Water-to-fly ash ratio was constant at 0.3

Rys. 4. Wytrzymałość na ściskanie obydwu typów badanych geopolimerów po 7 i 90 dniach w zależności od stosunku molowego $\mathrm{SiO}_{2} / \mathrm{Na}_{2} \mathrm{O}$. Stosunek wody do popiołu stały: 0,3

Lower water absorption values were obtained for the FFA-geopolymers than the DFA-geopolymers. An exception is the DFA-geopolymer with a $\mathrm{SiO}_{2}$-to- $\mathrm{Na}_{2} \mathrm{O}$ molar ratio of 1.25 with the lowest water absorption of all samples, amounting to $6.62 \%$ (Table 5). The water absorption decreases with an increasing $\mathrm{SiO}_{2}$-to- $\mathrm{Na}_{2} \mathrm{O}$ molar ratio up to 1.25 , with further increasing of the molar ratio causing an increase in water absorption. It can be

Table 5. Values of water absorption and coefficient of freezing for DFA- and FFA- geopolymers depending on different $\mathrm{SiO}_{2}$-to- $\mathrm{Na}_{2} \mathrm{O}$ molar ratios

Tabela 5. Wartości nasiąkliwości wodnej i mrozoodporności dla geopolimerów DFA i FFA w zależności od stosunku molowego $\mathrm{SiO}_{2} / \mathrm{Na}_{2} \mathrm{O}$

\begin{tabular}{|c|c|c|c|c|c|}
\hline \multirow{3}{*}{ Material } & water-to-fly ash & $\mathrm{SiO}_{2}$-to- $\mathrm{Na}_{2} \mathrm{O}$ & $\begin{array}{c}\mathrm{Na}_{2} \mathrm{O} \\
{[\%]}\end{array}$ & $\begin{array}{c}\text { Water absorption } \\
{[\%]}\end{array}$ & $\begin{array}{c}\text { Coeficient of } \\
\text { freezing }\end{array}$ \\
\hline \multirow{4}{*}{ DFA } & 0.3 & 0.75 & 8 & 14.91 & 0.77 \\
\cline { 2 - 6 } & 0.3 & 1.00 & 8 & 10.45 & 1.00 \\
\cline { 2 - 6 } & 0.3 & 1.25 & 8 & 6.62 & 1.05 \\
\cline { 2 - 6 } & 0.3 & 1.50 & 8 & 12.98 & 0.84 \\
\hline \multirow{5}{*}{ FFA } & 0.3 & 1.65 & 8 & 18.16 & 0.72 \\
\cline { 2 - 6 } & 0.3 & 0.75 & 8 & 11.57 & 0.67 \\
\cline { 2 - 6 } & 0.3 & 1.00 & 8 & 11.17 & 0.80 \\
\cline { 2 - 6 } & 0.3 & 1.25 & 8 & 10.27 & 0.79 \\
\cline { 2 - 6 } & 0.3 & 1.50 & 8 & 12.43 & 0.91 \\
\hline
\end{tabular}


observed that the values of water absorption measured for the DFA-geopolymers significantly differ from each other in contrast to the FFA-geopolymers with similar values of water absorption for all ratios.

No damage and no body disintegration of the fly ash geopolymer occurred during 50 freezing and defrosting cycles in an aqueous environment. On the contrary, higher compressive strength than the reference sample was obtained for the DFA-geopolymer with a $\mathrm{SiO}_{2}$-to- $\mathrm{Na}_{2} \mathrm{O}$ molar ratio of 1.25 after the frost resistance test. Resistance to alternating freezing and defrosting cycles of the DFA-geopolymer with a molar ratio of 1.00 was also good, possessing the same compressive strength as the reference sample. The values of compressive strength of all other geopolymers after frost resistance testing were decreased.

The values of compressive strength of the FFA-geopolymers were lower after 50 defrosting cycles when compared to reference samples without any frost resistance testing. The greatest decrease $(33 \%)$ in compressive strength was obtained for the geopolymer with a $\mathrm{SiO}_{2}$-to- $\mathrm{Na}_{2} \mathrm{O}$ molar ratio of 0.75 (Table 5). The FFA-geopolymers with molar ratios of 1.50 and 1.65 possess good resistance to alternating freezing and defrosting cycles, with their compressive strength following frost resistance testing being decreased by only 9 and $10 \%$, respectively.

Alkali activated fly ashes with a $\mathrm{SiO}_{2}$-to- $\mathrm{Na}_{2} \mathrm{O}$ molar ratio of 1.25 achieved the best results, and for this reason this ratio was chosen and utilized in the next experiments.

\subsection{Effect of the water-to-fly ash ratio}

Figure 5 shows the compressive strength of both types of geopolymers and their evolution over time ( 7 and 90 days) depending on different water-to-fly ash ratios. Water content in the mixtures was increased to improve the workability of mixtures. However, compressive strength of the fly ash geopolymers significantly decreases with increasing water content in the mixture. Constant $\mathrm{NaOH}$ content with increased water content in the activation solution resulted in reduced $\mathrm{NaOH}$ concentration. This has a negative effect on the compressive strength of the geopolymers because of the decreasing dissolution rate of the material. A higher initial proportion of water in the mixture results in increasing of geopolymer porosity (Steveson and Sagoe-Crentsil 2005a, b) which could be related to the increase in the water absorption of geopolymers with an increasing water-to-fly ash ratio. The FFA-geopolymers achieved higher values of water absorption than the DFA-geopolymers.

The compressive strengths of the fly ash geopolymers were lower after 50 defrosting cycles when compared to reference samples without any frost resistance testing (Table 6). No damage of the fly ash geopolymer occurred during the 50 freezing and defrosting cycles in an aqueous environment. An exception was the FFA-geopolymer with a water-to-fly ash ratio of 0.35 , where minor body disintegration occurred. However, no influence on the compressive strength was observed because this geopolymer possesses the same decrease in compressive strength as the geopolymer with a water-to-fly ash ratio of 0.30 , where no body disintegration occurred. 


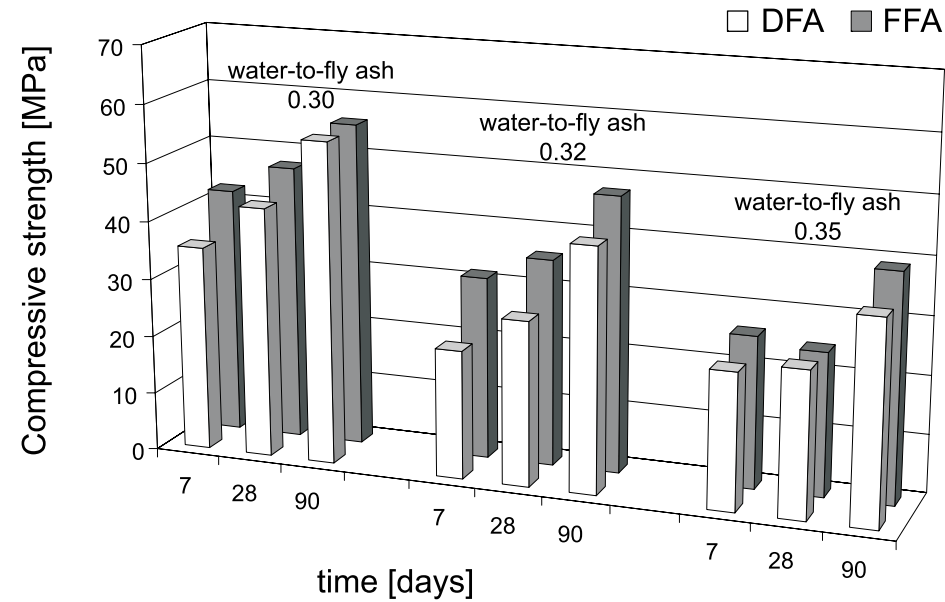

Fig. 5. Compressive strength of both types of examined geopolymers with their evolution over time (7 and 90 days) depending on different water-to-fly ash ratios

Rys. 5. Wytrzymałość na ściskanie obydwu typów badanych geopolimerów po 7 i 90 dniach w zależności od różnych stosunków wody do popiołu

Table 6. Values of water absorption and coefficient of freezing for DFA- and FFA- geopolymers depending on different water-to-fly ash ratios

Tabela 6. Wartości nasiąkliwości wodnej i mrozoodporności dla geopolimerów DFA i FFA w zależności od różnych stosunków wody do popiołu

\begin{tabular}{|c|c|c|c|c|c|}
\hline \multirow{3}{*}{ Material } & water-to-fly ash & $\mathrm{SiO}_{2}$-to- $\mathrm{Na}_{2} \mathrm{O}$ & $\begin{array}{c}\mathrm{Na}_{2} \mathrm{O} \\
{[\%]}\end{array}$ & $\begin{array}{c}\text { Water absorption } \\
{[\%]}\end{array}$ & $\begin{array}{c}\text { Coeficient of } \\
\text { freezing }\end{array}$ \\
\hline \multirow{3}{*}{ DFA } & 0.30 & 1.25 & 8 & 6.62 & 1.05 \\
\cline { 2 - 6 } & 0.32 & 1.25 & 8 & 9.42 & 0.73 \\
\cline { 2 - 6 } & 0.35 & 1.25 & 8 & 9.63 & 0.79 \\
\hline \multirow{3}{*}{ FFA } & 0.30 & 1.25 & 8 & 10.27 & 0.79 \\
\cline { 2 - 6 } & 0.32 & 1.25 & 8 & 11.44 & 0.70 \\
\cline { 2 - 6 } & 0.35 & 1.25 & 8 & 14.68 & 0.71 \\
\hline
\end{tabular}




\section{Conclusions}

The geopolymers tested in this study were based on fly ashes with a high content of unburned coal residues (more than $20 \mathrm{wt} \%$ loss on ignition) taken either directly from a fly ash hopper or from a sludge bed where the ash was exposed to atmospheric influences and erosion for a period of $2-5$ years. The testing shows that the fresh fly ash is reactive. Geopolymers prepared from this fly ash possess higher compressive strength than geopolymers prepared from deposited fly ash. On the other hand, DFA-geopolymers possess lower water absorption, and their resistance to alternating cycles is better. Some of the DFA-geopolymers exposed to 50 freezing and defrosting cycles in an aqueous environment achieved higher compressive strengths when compared to reference samples without any frost resistance testing. This type of binder can be used in geopolymer concrete for production material for paving, shaped pieces or kerbs.

This work was supported by the research grant project VEGA 1/1222/12 and APVV 0423-11

\section{REFERENCES}

Criado et al. 2007 - Criado, M., Fernández-Jiménez, A. and Palomo, A. 2007. Alkali activation of fly ash: Effect of the $\mathrm{SiO}_{2} / \mathrm{Na}_{2} \mathrm{O}$ ratio. Part I: FTIR study. Microporous and Mesoporous Materials vol. 106, pp. 180-191.

Davidovits, J., 1990. Geopolymers: Inorganic Polymeric new materials. Journal of thermal analysis vol. 37 , pp. 1633-1656.

Davidovits J. 2008. Geopolymer: Chemistry and applications. Ed. 2. Institut Géopolymčre, France.

Duxson et al. 2007 - Duxson, P., Mallicoat, S.W., Lukey, G.C., Kriven, W.M. and Van Deventer, J.S.J. 2007. The effect of alkali and $\mathrm{Si} / \mathrm{Al}$ ratio on the development of mechanical properties of metakaolin-based geopolymers. Colloids and Surfaces A: Physicochem. Eng. Aspects vol. 292, pp. 8-20.

Fernández-Jiménez, A. and Palomo, A. 2003. Characterisation of fly ashes. Potential reactivity as alkaline cements. Fuel vol. 82, pp. 2259-2265.

Fernández-Jiménez et al. 2006a - Fernández-Jiménez, A., Palomo, A., Sobrados, I. and Sanz, J. 2006. The role played by the reactive alumina content in the alkaline activation of fly ashes. Microporous and Mesoporous Materials vol. 91, pp. 111-119.

Fernández-Jiménez et al. 2006b - Fernández-Jiménez, A., De la Torre, A.G., Palomo, A., López-Olmo, G., Alonso, M.M. and Aranda, M.A.G. 2006. Quantitative determination of phases in the alkali activation of fly ash. Part I. Potential ash reactivity. Fuel vol. 85, pp. 625-634.

Ha et al. 2005 - Ha, T.H., Muralidharan, S., Bae ,J.H., Ha ,Y.C., Lee, H.G., Park, K.W. and Kim, D.K. 2005. Effect of unburned carbon on the corrosion performance of fly ash cement mortar. Construction and Building Materials vol. 19, pp. 509-515.

Kumar, S. and Kumar, R. 2011. Mechanical activation of fly ash: Effect on reaction, structure and properties of resulting geopolymer. Ceramics International vol. 37, pp. 533-541.

Lee, W.K.W. and Van Deventer, J.S.J. 2002. The effect of ionic contaminants on the early-age properties of alkali-activated fly ash-based cements. Cement and Concrete Research vol. 32, pp. 577-584.

Panias et al. 2007 - Panias, D., Giannopoulou, I.P. and Perraki, T. 2007. Effect of synthesis parameters on the mechanical properties of fly ash-based geopolymers. Colloids and Surfaces A: Physicochemical and Engineering Aspects vol. 301, pp. 246-254.

Phair, J.W. and Van Deventer, J.S.J. 2001. Effect of silicate activator pH on the leaching and material characteristics of waste-based inorganic polymers. Minerals Engineering vol. 14, pp. 289-304. 
Steveson, M. and Sagoe-Crentsil, K. 2005a. Relationships between composition, structure and strength of inorganic polymers. Part 1 Metakaolin-derived inorganic polymers. Journal of materials science vol. 40, pp. 2023-2036.

Steveson, M. and Sagoe-Crentsil, K. 2005b. Relationships between composition, structure and strength of inorganic polymers. Part 2 Fly ash-derived inorganic polymers. Journal of materials science vol. 40, pp. 4247-4259.

Škvára et al. 2005 - Škvára, F., Jílek, T. and Kopecký, L. 2005. Geopolymer materials based on fly ash. Ceramics Silikáty vol. 49, pp. 195-204.

Temuujin et al. 2009 - Temuujin, J., Williams, R.P. and Van Riessen, A. 2009. Effect of mechanical activation of fly ash on the properties of geopolymér cured at ambient temperature. Journal of Materials Processing Technology vol. 209, pp. 5276-5280.

Van Jaarsveld et al. 1997 - Van Jaarsveld, J.G.S., Van Deventer, J.S.J. and Lorenzen, L. 1997. The potential use of geopolymeric materials to immobilise toxic metals: Part I. Theory and applications. Minerals Engineering vol. 10, pp. 659-669.

Van Jaarsveld et al. 1999 - Van Jaarsveld, J.G.S., Van Deventer, J.S.J. and Schwartzman, A. 1999. The potential use of geopolymeric materials to immobilise toxic metals: Part II. Material and leaching characteristics. Minerals Engineering vol. 12, pp. 75-91.

Van Jaarsveld et al. 2003 - Van Jaarsveld, J. G. S., Van Deventer, J.S.J. and Lukey, G.C. 2003. The characterisation of source materials in fly ash-based geopolymers. Materials Letters vol. 57, pp. 1272-1280.

$\mathrm{Xu}, \mathrm{H}$. and Van Deventer, J.S.J. 2000. The geopolymerisation of alumina-silicate materials. International Journal of Mineral Processing vol. 59, pp. 257-266.

$\mathrm{Xu}, \mathrm{H}$. and Van Deventer, J.S.J. 2002. Geopolymerization of multiple minerals. Minerals Engineering vol. 15, pp. 1131-1139.

Yip et al. 2005 - Yip, C.K., Lukey, G.C. and Van Deventer, J.S.J. 2005. The coexistence of geopolymeric gel and calcium silicate hydrate at the early stage of alkaline activation. Cement and Concrete Research vol. 35, pp. 1688-1697.

Yip et al. 2008 - Yip, C.K., Lukey, G.C., Provis, J.L. and Van Deventer, J.S.J. 2008. Effect of calcium silicate sources on geopolymerisation. Cement and Concrete Research vol. 38, pp. 554-564.

\section{AKTYWACJA ALKALICZNA POPIOŁÓW LOTNYCH ZE SPALANIA WEGLA KAMIENNEGO, WYKAZUJACCYCH WYSOKA STRATE PRAŻENIA, POCHODZĄCYCH Z BIEŻĄCEJ DZIALALNOŚCI I ZE ZWALOWISKA}

Słowa kluczowe

aktywacja alkaliczna, popioły lotne, strata prażenia

\section{Streszczenie}

Elektrownie i elektrociepłownie stosujące węgiel jako paliwo mają istotne znaczenie jako źródła energii, choć z drugiej strony wytwarzają duże ilości popiołów lotnych ze spalania węgli. Tylko mała część tych popiołów jest użytkowana jako surowce odpadowe. Zazwyczaj popioły lotne są deponowane w osadnikach, co stwarza poważne zagrożenie środowiskowe. Możliwości zagospodarowania popiołów lotnych stwarza przede wszystkim przemysł materiałów budowlanych; tym niemniej użytkowanie popiołów lotnych z podwyższoną zawartością niespalonych cząstek węgla, co wyraża się wartością straty prażenia, jest ograniczone do popiołów wykazujących stratę prażenia 2-5\% zgodnie z europejską normą EN 206-1. Dlatego też popioły lotne z wysoką zawartością niespalonych cząstek węgla są deponowane w osadnikach. Depozycja popiołów lotnych, biorąc pod uwagę także czynniki 
egzogeniczne i biogeniczne, powoduje zmiany składu chemicznego i fazowego popiołów, co powoduje, że możliwości ich późniejszego wykorzystania jako surowce odpadowe, jeszcze bardziej maleją.

Obecnie, jedyną możliwością użytkowania popiołów lotnych wykazujących wysoką stratę prażenia, jest synteza geopolimerów. Te nowe materiały nieorganiczne są otrzymywane w wyniku reakcji nieorganicznej polikondensacji glinokrzemianów z krzemianem sodu w środowisku wysoce alkalicznym.

Praca zajmuje się produkcją spoiw geopolimerowych otrzymywanych w wyniku aktywacji alkalicznej popiołów lotnych pochodzących z bieżącej działalności oraz ze zwałowiska. Popioły lotne pochodzą ze spalania węgla kamiennego w kotłach pyłowych, wykazując wysoką zawartość niespalonych cząstek węgla. Wartość straty prażenia w tych popiołach przekracza $20 \%$. Są one aktywowane alkalicznie roztworami wodorotlenku sodowego i szkła wodnego. Analizowano zależność wytrzymałości na ściskanie syntetyzowanych geopolimerów od stosunku $\mathrm{SiO}_{2} / \mathrm{Na}_{2} \mathrm{O}$, zawartości $\mathrm{Na}_{2} \mathrm{O}$ i zawartości wody. Wytrzymałość na ściskanie aktywowanych alkalicznie popiołów lotnych deponowanych (DPA) i z bieżącej działalności (FFA) wynosi odpowiednio 39,8 $\mathrm{MPa}$ i 46,8 $\mathrm{MPa}$ po 7 dniach i wzrasta $z$ czasem.

\title{
ALKALI ACTIVATION OF FRESH AND DEPOSITED BLACK COAL FLY ASH WITH HIGH LOSS ON IGNITION
}

\author{
Key words
}

alkali activation, fly ash, loss on ignition (LOI)

Abstract

Heating plants and power stations using coal as a fuel are employed worldwide as energy sources, consequently generating large quantities of fly ashes. Only a small part of these fly ashes are used as a secondary raw material. Most commonly, fly ash is deposited at sludge bed where it poses substantial ecological risks. Possibilities of utilizing fly ashes are mainly found in the construction industry; however, utilization of fly ash with a high content of unburned coal residues, expressed by loss on ignition (LOI), is limited to 2-5\% LOI by the European standard STN EN 206-1. That is why fly ash with a high content of unburned coal residues is deposited at sludge bed. Fly ash deposition, hand in hand with exogenous and biogenous factors, changes the chemical and phase composition of fly ashes so the possibility for their further utilization as a secondary raw material is even more diminished.

Currently, one possibility for the use of high-LOI fly ashes is in the synthesis of geopolymers. These new materials are inorganic materials obtained from an inorganic polycondensation reaction of solid aluminosilicates with sodium silicate solution in a highly alkaline environment.

This paper deals with the production of geopolymer binders from the alkaline activation of fresh and deposited fly ash. The fly ashes originated from black coal fired in melting boilers, and have a high content of unburned coal residues. Content of LOI in both fly ashes exceeds $20 \%$. The fly ashes are alkali activated with solutions containing sodium hydroxide and sodium waterglass. The analysis examines the effects of the $\mathrm{SiO}_{2}$-to- $\mathrm{Na}_{2} \mathrm{O}$ ratio, $\mathrm{Na}_{2} \mathrm{O}$, as well as the water content in the synthesis of fly ash-based geopolymers on their compressive strength. The compressive strength of alkali-activated, deposited fly ash (DPA) and fresh fly ash (FFA) were $39.8 \mathrm{MPa}$ and $46.8 \mathrm{MPa}$ after 7 days, respectively. Their compressive strength increased with time. 
